\title{
Physiological Intermolecular Modification Spectroscopy for the Prediction of Response to Anti-Tumor Necrosis Factor Therapy in Patients with Inflammatory Bowel Diseases
}

\author{
Pierre Eftekhari ${ }^{a, b} \quad$ Lisa Glaubitz ${ }^{c}$ Matthias Breidert ${ }^{d}$ \\ Markus Friedrich Neurath ${ }^{c}$ Raja Atreya ${ }^{c}$

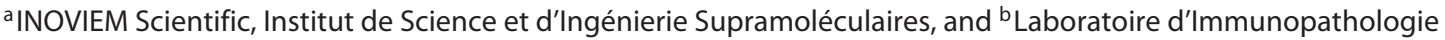 \\ et Chimie Thérapeutique, CNRS UPR 3572, Strasbourg, France; ' $M e d i c a l$ Clinic 1, Friedrich Alexander University \\ Erlangen-Nuremberg, Erlangen, and ${ }^{\mathrm{d}}$ District Hospital Kösching/Eichstätt, Teaching Hospital of the Technical \\ University Munich, Kösching, Germany
}

\section{Key Words}

Anti-tumor necrosis factor therapy - Crohn's disease . Inflammatory bowel disease . Physiological intermolecular modification spectroscopy . Ulcerative colitis

\section{Abstract \\ Background/Aims: Anti-tumor necrosis factor (TNF) anti- bodies have clinical efficiency only in a subgroup of patients with inflammatory bowel diseases (IBD). Prediction of clini- cal response is a critical clinical problem. Physiological inter- molecular modification spectroscopy (PIMS) is a label-free technology performed in physiological conditions. PIMS en- ables real-time monitoring of dynamic molecular resonance of entire proteins and macromolecules of an individual. The aim of this study was to explore the capacity of PIMS to dis- criminate IBD patients regarding response to anti-TNF treat- ment. Methods: Protein extracts of peripheral blood mono- nuclear cells (PBMC) from 30 outpatients diagnosed with ul- cerative colitis (UC) or Crohn's disease (CD) and treated with infliximab were subjected to PIMS analysis in a blinded trans- versal study. Total protein from each patient's PBMCs was challenged with infliximab. Dynamic changes in macromo-}

(2) 2014 S. Karger AG, Basel

0257-2753/14/0324-0446\$39.50/0 lecular interaction were registered while the temperature rose from -37 to $37^{\circ} \mathrm{C}$. Individual macromolecular volume and molecular elasticity were determined for each patient. Results: Clinical data revealed that $67 \%$ of UC and $79 \%$ of CD patients responded to infliximab therapy during the 3-month study period based on their respective clinical activity score. These results confirm that PIMS data predicted response to anti-TNF therapy with an accuracy of $96 \%$. Conclusion: PIMS stratified IBD patients into two groups, responders and nonresponders, which correlated with the clinical efficacy of anti-TNF therapy. PIMS seems to be a powerful technology to adapt IBD treatment to the individual patient. Further studies with PIMS might enable to predict clinical response to biological treatment in IBD patients before the therapy is initiated.

(c) 2014 S. Karger AG, Basel

\section{Introduction}

Ulcerative colitis (UC) and Crohn's disease (CD) are the most important entities of inflammatory bowel diseases (IBD). Both diseases are characterized by acute/

\section{KARGER}

E-Mail karger@karger.com www.karger.com/ddi
Dr. Pierre Eftekhari

ISIS

8 Allée Gaspard Monge

FR-67083 Strasbourg (France)

E-Mail p.eftekhari@inoviem.com 
chronic, destructive inflammation of the intestinal mucosa. The annual incidence of IBD is $3-8.5 / 100,000$ in European countries, and as many as 2.2 million individuals in Europe and 1.4 million individuals in the United States suffer from IBD, with overall health care costs of more than EUR 2.5 and 1.2 billion, respectively [1]. The immunopathological processes underlying $\mathrm{CD}$ have not been fully elucidated. To date, there is no causal treatment because the pathogenesis of IBD is still unclear. New treatment options are based on the concept of a more targeted therapy. This is reflected by the therapeutic efficacy of antibodies against tumor necrosis factor (TNF), which has been identified as one of the central proinflammatory cytokines in IBD immunopathogenesis. The chimeric monoclonal antibody infliximab and the human monoclonal antibody adalimumab have proven similar therapeutic efficacy in patients with IBD and have therefore both been approved for the induction and maintenance of remission in IBD patients in most parts of Europe [2, 3]. However, about 50\% of IBD patients do not respond to treatment with an anti-TNF antibody and there are no reliable predictors for therapeutic success $[4,5]$. Moreover, anti-TNF therapy may induce severe side effects (opportunistic infections, allergic reactions, skin disorders and lupus-like autoimmunity) and result in a high economic burden, with costs equaling nearly EUR 25,000/patient per year [6]. Classifying IBD patients is crucial regarding therapeutic decisions. Therefore, there is an increasing interest in the discovery of new IBD biomarkers able to predict the future course of the disease and to improve the diagnosis and treatment of IBD. These attempts have been restricted to genome identification for a long period. Recent technical advances, e.g. in the field of proteomics, subproteomics or metaboleomics, have gained marked interest, giving new hopes for biomarker identification in the field of IBD. Genome-wide analyses have led to the identification of more than 163 different genes associated with IBD $[7,8]$. Proteomic and subproteomic analysis have additionally identified a large number of different proteins dependent on the methodological approach, but currently these insights do not have any impact on clinical practice in IBD.

A very efficient way to improve treatment efficacy as well as deciphering CD and UC biomarkers is the use of therapeutics with proven clinical efficacy in these diseases. Fair examples in this regard are already marketed biological drugs, such as anti-TNF antibodies. Thanks to this approach, we may be able to stratify patients with respect to treatment (individualized medicine). In turn, an individualized medicine based on drug efficiency covers two major aspects: one is to discriminate responders from nonresponders to anti-TNF therapy. Another aspect is the identification of biomarkers, which might be able to predict the clinical course of IBD or give indication of its possible progression. This consists of having indications on treatment efficiency, as early as possible, through precise information on the therapeutic index and identification of an adapted individualized treatment.

This methodological or technological interface should be straightforward, easy to handle, fast and able to reflect the global state of each patient with particular emphasis on IBD. Physiological intermolecular modulation spectroscopy (PIMS) has been developed to take these requirements into account (fig. 1).

It is widely appreciated that almost all proteins and other biological macromolecules exist in vivo, at least transiently, as components of structural and functional complexes. This transient interaction in simple component solutions has been studied using a well-established Rayleigh light scattering (LS) method which reflects molecular oscillation [9-14]. Protein association, protein unfolding, protein aggregation and cellular crowding are known to affect the normal function of cellular systems [15-21]. Another physiochemical property of biological molecules is their absorption in the infrared range. Infrared absorption spectroscopy (IRAS) is a powerful biochemical analysis tool as it extracts detailed molecular structural information in a label-free fashion. Biological macromolecules can be studied using IRAS. It is also one of the classical methods to determine the structure of small molecules due to its sensitivity to chemical composition and molecule architecture. Therefore, IRAS is a valuable tool for the investigation of protein structure, the molecular mechanism of protein reactions and protein folding, unfolding and miswording [22-31]. IRAS has a large application range from small soluble proteins to large membrane proteins, a high time resolution down to $1 \mu$ s with moderate effort and often a short measuring time, and a low amount of sample is required (typically 10-100 $\mu \mathrm{g}$ ). Biological molecules do not exist alone, as they are always surrounded by water. The interaction and impact of water on proteins is reflected by the change in the proton spin of water molecules and thus molecular resonance on the surface of proteins, which is deduced from nuclear magnetic resonance relaxation [32-36].

Based on these and the acquired knowledge on LS, the novel PIMS method has been developed. PIMS is a tech- 
Fig. 1. Relation between the current state of the art and the important role of PIMS. PIMS is proposed to reconcile the data issued from the -omics with clinical data and bridges the gap between -omics.

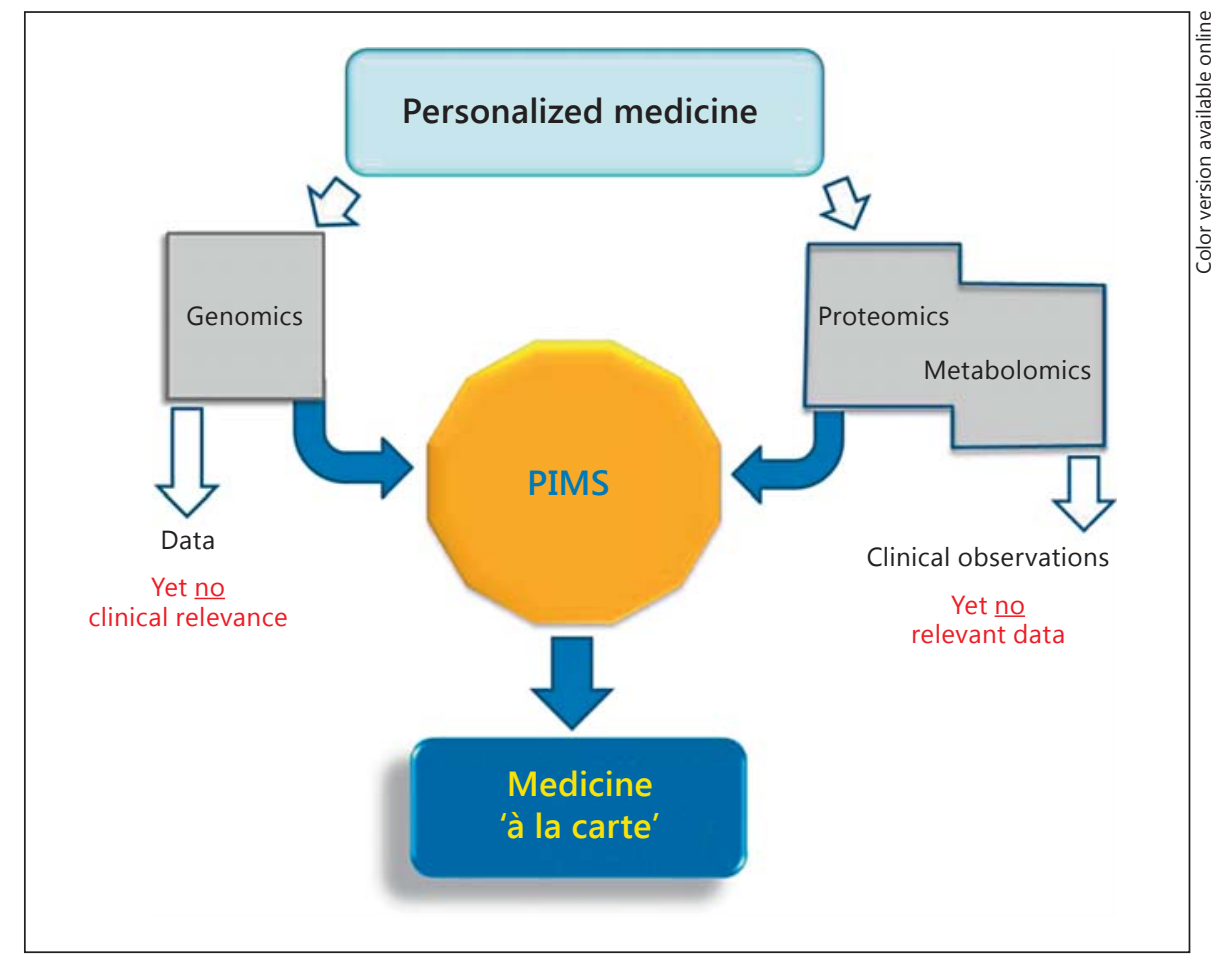

nology based on dynamic molecular resonance of proteins and macromolecules. PIMS is a label-free technology that is able to study protein-protein and protein-solvent interactions in multicomponent solutions. It provides individual real-time dynamic fingerprints of total physiological macromolecular assemblies in a tissue in the presence and absence of exogenous molecules (drug or drug candidates, peptides or proteins). It reflects the patient's molecular capacity to respond to the drug and allows to discriminate different subpopulations of patients regarding response to a specific treatment. It differentiates responders from nonresponders to a given treatment.

It takes into account a combination readout based on changes in the resonance of water molecules and macromolecular conformation. The latter can be used to predict treatment efficacy. PIMS provides very significant opportunities in the field of personalized medicine and biomarkers.

The aim of this study is to predict response to antiTNF treatment in IBD patients using the PIMS method on peripheral blood mononuclear cells (PBMC) of these patients before deblinding. The IBD patients included in this study were treated with an anti-TNF antibody and the response to the ongoing therapy was evaluated after a treatment period of 3 months.

\section{Patients and Methods}

\section{Patients}

Venous blood was drawn from 30 consecutive outpatients (10 females with a mean age of $40.8 \pm 16.4$ years and 20 males with a mean age of $41.5 \pm 18.6$ years) with an established diagnosis of UC $(\mathrm{n}=18)$ or $\mathrm{CD}(\mathrm{n}=12)$ who had previously been treated with the anti-TNF antibody infliximab in the Medical Clinic 1 of the University of Erlangen.

Clinical disease activity was assessed in each patient using the Harvey-Bradshaw index (HBI) in CD and the total Mayo score (MS) in UC patients. Clinical disease activity scores were assessed prior to the initiation of the first infliximab treatment in all patients. All patients in this transversal study were reassessed regarding their HBI after 12 weeks $( \pm 1)$ and the total MS after 12 weeks. Endoscopic examination, which contributed to the calculation of the total MS, was performed after $12 \pm 3$ weeks of therapy with infliximab. Response to therapy in CD patients was defined as a 3 -point reduction in the HBI and remission as a HBI score $<4$ points after 12 weeks of infliximab [37]. In UC, response to therapy was defined as a reduction in the total Mayo score by at least 3 points and $30 \%$ and remission was defined as a total $\mathrm{MS}<3$ points after 12 weeks of infliximab therapy [38]. Patients who responded or went into remission following infliximab according to the above-mentioned criteria were classified as 'positive responders' to therapy, while the other patients were characterized as 'negative responders' to therapy. Patients who remained in remission after infliximab therapy initiation were also classified as 'positive responders'.

All patients received infliximab therapy at weeks 0,2 and 6 during the time of the study. Infliximab doses given were $5 \mathrm{mg} / \mathrm{kg}$ per 

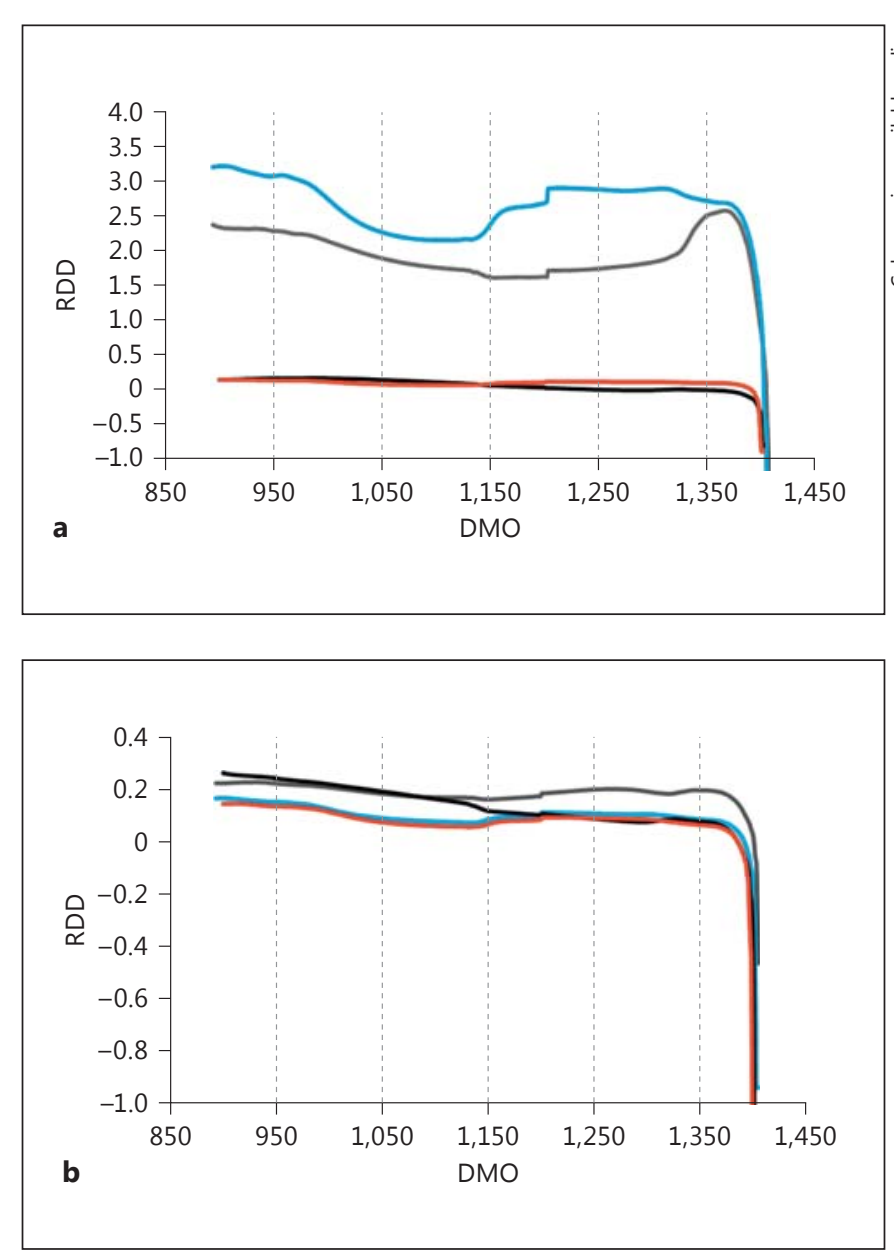

Fig. 2. Ratio of RDD based on 2 patients' $\mathrm{ME}$ from -10 to $-5^{\circ} \mathrm{C}$. a $\mathrm{ME}$ for a responder to anti-TNFa therapy at $-10^{\circ} \mathrm{C}$ does not change in the presence/absence of infliximab (red and black lines, respectively). At $-5^{\circ} \mathrm{C}, \mathrm{ME}$ is modified in the presence of infliximab (gray line) compared to the blue line in the absence of infliximab. $\mathbf{b}$ ME for a non-responding patient to anti-TNFa therapy at -10 and $-5^{\circ} \mathrm{C}$. There are no changes in presence and absence of infliximab (red and black lines, respectively; colors are shown in the online version only).

patient. Concomitant medication consisted of mesalazine, thiopurines, corticosteroids or no other parallel therapy. The dose of concomitant medications was not increased during the study period. Patient characteristics (gender, age, treatment, response to treatment and state of the disease) were blinded. Approval was granted by the competent Ethics Committee of the University of Erlangen. All patients gave written informed consent to participate in this study.

\section{PBMC Isolation}

From each patient, $20 \mathrm{ml}$ of whole blood were collected in heparin EDTA Vacutainer tubes. The blood was diluted with phosphate-buffered saline (PBS; ratio: $2 / 3, \mathrm{v} / \mathrm{v}$ ). Thirty milliliters of whole blood/PBS mixture were gently placed over $20 \mathrm{ml}$ of LSM 1077 lymphocyte separation medium (PAA Laboratories, GmbH, Pasching, Austria) using two 50-ml conic tubes sufficient enough for PMBC separation of $40 \mathrm{ml}$ of diluted blood. PBMC were separated by centrifugation at $805 \mathrm{~g}$ for $20 \mathrm{~min}$ at $18^{\circ} \mathrm{C}$. The isolated PBMC were washed 2 times in PBS at $652 \mathrm{~g}$. Pelleted PBMC were frozen and stored at $-80^{\circ} \mathrm{C}$ until use.

\section{Physiological Intermolecular Modification Spectroscopy}

Total protein concentrations of each individual cellular extract from the patients' PBMC were determined using the BCA protein assay (Pierce, Thermo Scientific, Rockford, Ill., USA) according to the manufacturer's recommendations. Protein $(1 \mu \mathrm{g})$ was mixed with $10^{-6} \mathrm{M}$ infliximab. The blank consisted only of $1 \mu \mathrm{g}$ of total protein from the same patient's PBMC with the same preparation using identical diffraction cells. PIMS were recorded accordingly when cellular extracts in physiological conditions were frozen at $-37^{\circ} \mathrm{C}$. Macromolecular spectra were registered as the temperature within the sample rose from -37 to $37^{\circ} \mathrm{C}$.

\section{PIMS Data Analysis}

In order to get maximum information of the individual macromolecular spectra provided, the following distinct variables were studied:

\section{Variable 1}

The calculated individual macromolecular volume (IMV) is defined as the total macromolecular spectral change from -37 to $37^{\circ} \mathrm{C}$ due to macromolecular conformational changes in the absence and presence of a drug, expressed as a change in relative differential diffraction as a function of wavelength and temperature. A small change in volume indicates a minor impact of the treatment, whereas a major change underlines significant macromolecular rearrangements and, therefore, a higher probability for a therapeutic effect.

\section{Variable 2}

Molecular elasticity (ME) is defined as a change in relative differential diffraction for temperatures of -10 and $-5^{\circ} \mathrm{C}$ as a function of wavelength. The ME variable is a fine-tuning button, allowing to calculate the impact of the drug or xenobiotic on ME (fig. 2). The higher the intramolecular potential energy, the lower the degree of ME. It is calculated using the following formula:

$f(x)_{-5^{\circ} \mathrm{C}}=\sum_{n=850}^{1,450}(\mathrm{DMO} \times \mathrm{RDD}) / f(x)_{-10^{\circ} \mathrm{C}}=\sum_{n=850}^{1,450}(\mathrm{DMO} \times \mathrm{RDD})$,

where DMO is differential molecular oscillation and RDD is relative dynamic diffraction at -10 and $-5^{\circ} \mathrm{C}$.

Patients with a ratio of $\mathrm{ME}$ higher than zero were considered as responders. A ratio equal to zero was considered as borderline.

$\mathrm{DMO}$ is defined as the difference in molecular resonance as a function of time and surrounding environment in the presence of infliximab compared to the blank.

RDD depends on surrounding water molecules in the presence of infliximab compared to the blank. Any change induced by infliximab in the patients' protein assemblies will change water diffraction as the temperature rises from -10 to $-5^{\circ} \mathrm{C}$. 
Table 1. Clinical data of the CD patients

\begin{tabular}{|c|c|c|c|c|c|}
\hline $\begin{array}{l}\text { Patient } \\
\text { No. }\end{array}$ & Sex & Diagnosis & $\begin{array}{l}\text { HBI } \\
\text { week } 0\end{array}$ & $\begin{array}{l}\text { HBI } \\
\text { week } 12 \pm 1\end{array}$ & Clinical result \\
\hline 1 & $\mathrm{~m}$ & $\mathrm{CD}$ & 11 & 9 & no response \\
\hline 2 & $\mathrm{f}$ & CD & 4 & 7 & no response \\
\hline 3 & $\mathrm{~m}$ & $\mathrm{CD}$ & 9 & 12 & no response \\
\hline 4 & $\mathrm{~m}$ & $\mathrm{CD}$ & 3 & 2 & remission \\
\hline 5 & $\mathrm{~m}$ & $\mathrm{CD}$ & 7 & 2 & remission \\
\hline 6 & $\mathrm{f}$ & $\mathrm{CD}$ & 11 & 5 & response \\
\hline 7 & $\mathrm{~m}$ & $\mathrm{CD}$ & 4 & 1 & remission \\
\hline 8 & $\mathrm{~m}$ & $\mathrm{CD}$ & 5 & 1 & remission \\
\hline 9 & $\mathrm{f}$ & $\mathrm{CD}$ & 1 & 2 & remission \\
\hline 10 & $\mathrm{~m}$ & $\mathrm{CD}$ & 16 & 12 & response \\
\hline 11 & $\mathrm{f}$ & $\mathrm{CD}$ & 4 & 3 & remission \\
\hline 12 & $\mathrm{~m}$ & $\mathrm{CD}$ & 6 & 3 & remission \\
\hline
\end{tabular}

\section{Results}

\section{Clinical Response to Infliximab}

In the group of patients with CD, 9 patients were 'positive responders' (75\%) and 3 were 'negative responders' $(25 \%)$ to the 12 -week infliximab treatment (table 1). In the group of patients with UC, 12 patients turned out to be 'positive' (67\%) and 6 patients 'negative responders' (33\%) to the 12 -week infliximab treatment (table 2). CD patients 4 and 9 and UC patients 2, 12 and 13 were in remission when the first infliximab application took place and were still in remission when they were reassessed after 12 weeks (table 1,2). These patients were also classified as 'positive responders' to infliximab.

\section{Individual Macromolecular Volume}

PIMS results plotted in three axes (DMO, RDD and temperature) revealed three different infliximab groups compared to the baseline (fig. 3). One group showed intrinsically higher LS capacity, which was attenuated or abolished in the presence of infliximab (group A). A second group showed low LS capacity, which was increased in the presence of infliximab (group B). The third group had either high or low intrinsic LS capacities and remained unchanged in the presence of infliximab (group C).

\section{Molecular Elasticity}

Infliximab changed $\mathrm{ME}$ with regard to altered molecular resonance and therefore the pattern of scattered light between -10 and $-5^{\circ} \mathrm{C}$. We identified two distinct groups. Among IBD patients, we characterized a responder group $(n=21)$ and a nonresponder group $(n=9)$. More precisely,
Table 2. Clinical data of the UC patients

\begin{tabular}{|c|c|c|c|c|c|}
\hline $\begin{array}{l}\text { Patient } \\
\text { No. }\end{array}$ & Sex & Diagnosis & $\begin{array}{l}\text { MS } \\
\text { week } 0\end{array}$ & $\begin{array}{l}\text { MS } \\
\text { week } 12 \pm 3\end{array}$ & Clinical result \\
\hline 1 & $\mathrm{~m}$ & $\mathrm{UC}$ & 4 & 11 & no response \\
\hline 2 & $\mathrm{f}$ & UC & 2 & 0 & remission \\
\hline 3 & $\mathrm{~m}$ & $\mathrm{UC}$ & 9 & 10 & no response \\
\hline 4 & $\mathrm{~m}$ & $\mathrm{UC}$ & 6 & 2 & remission \\
\hline 5 & $\mathrm{~m}$ & $\mathrm{UC}$ & 9 & 0 & remission \\
\hline 6 & $\mathrm{~m}$ & UC & 4 & 6 & no response \\
\hline 7 & f & $\mathrm{UC}$ & 7 & 2 & remission \\
\hline 8 & $\mathrm{~m}$ & $\mathrm{UC}$ & 8 & 5 & response \\
\hline 9 & $\mathrm{~m}$ & $\mathrm{UC}$ & 4 & 2 & remission \\
\hline 10 & $\mathrm{~m}$ & $\mathrm{UC}$ & 6 & 6 & no response \\
\hline 11 & $\mathrm{~m}$ & $\mathrm{UC}$ & 7 & 2 & remission \\
\hline 12 & $\mathrm{f}$ & UC & 2 & 2 & remission \\
\hline 13 & $\mathrm{f}$ & $\mathrm{UC}$ & 2 & 1 & remission \\
\hline 14 & $\mathrm{~m}$ & $\mathrm{UC}$ & 5 & 2 & remission \\
\hline 15 & $\mathrm{f}$ & $\mathrm{UC}$ & 3 & 3 & no response \\
\hline 16 & $\mathrm{~m}$ & UC & 5 & 3 & no response \\
\hline 17 & $\mathrm{~m}$ & $\mathrm{UC}$ & 4 & 1 & remission \\
\hline 18 & $\mathrm{~m}$ & $\mathrm{UC}$ & 10 & 7 & response \\
\hline
\end{tabular}

PIMS prediction in regard to $\mathrm{CD}$ identified 10 responders (83\%) and 2 nonresponders (17\%). In UC, PIMS characterized 12 patients as responders (67\%) and 6 patients as nonresponders (33\%). These results are summarized in table 3.

One patient was considered as borderline $(\mathrm{ME}=0)$. The patient was considered as nonresponder as there were no differences between the IMV at baseline and in the presence of infliximab. The results are summarized in table 3.

Clinical responses confirmed PIMS prediction in $96 \%$. In 1 of these patients, PIMS prediction was not in line with the clinical response to infliximab therapy; this patient with $\mathrm{ME}=1$ was considered as a nonresponder, but clinically response to anti-TNF therapy was noted (fig. 4).

\section{Discussion}

Anti-TNF antibodies have established themselves as a valuable treatment option in IBD patients and are widely used in daily clinical practice nowadays [4]. However, about $50 \%$ of the patients do not respond to anti-TNF therapy [39] and there are currently no reliable biomarkers that may allow the stratification of patients into responders or nonresponders to therapy prior to its initiation. Finding a novel approach to establish predictive biomarkersfor therapeutic response is therefore an important 
Fig. 4. Ratio of RDD based on 2 patients' $\mathrm{ME}$ from -10 to $-5^{\circ} \mathrm{C}$ after deblinding of clinical data. Patients with a value $\geq 0$ were considered responders.

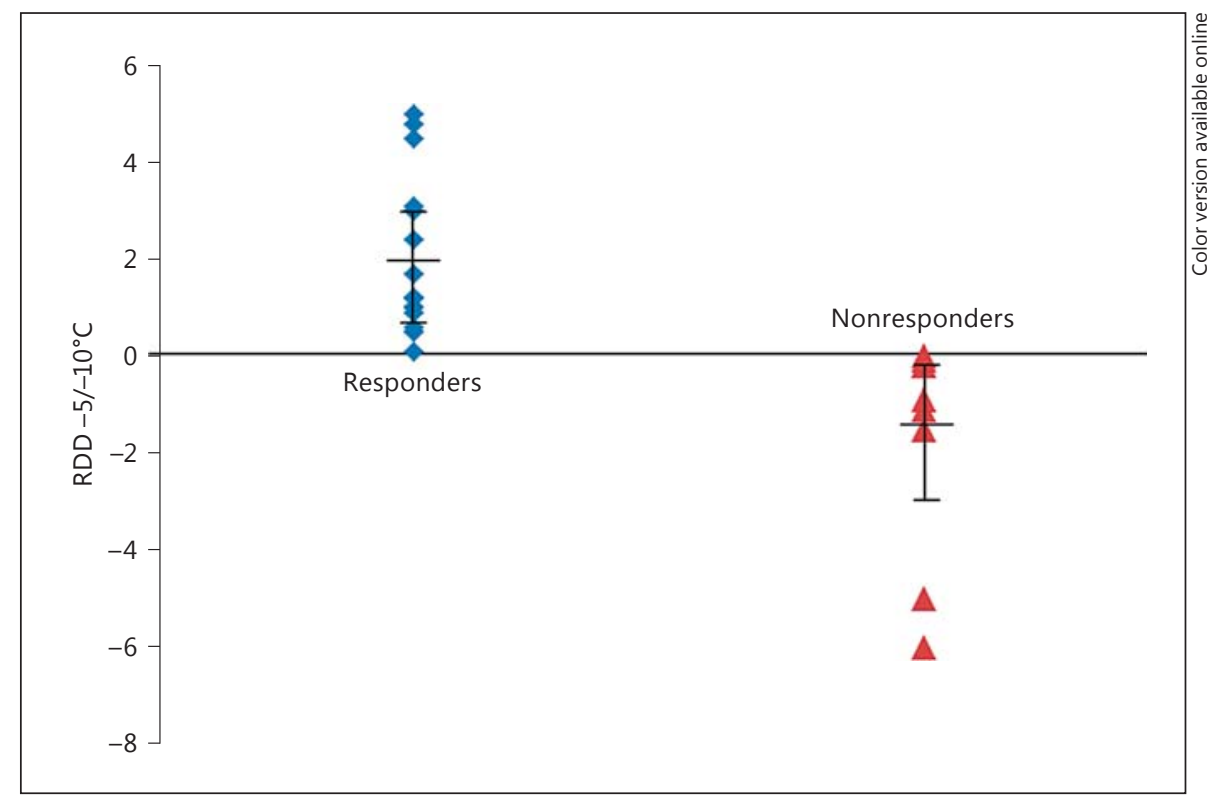

clinical aim, as it is not only important for the patients' well-being but would also avoid unnecessary side effects in patients with no or minor therapeutic benefit and would also reduce the expenses of the national health institute for individual health care.

The pathophysiology of IBD, which may vary between patients, poses the first problem to find a reliable biomarker for therapeutic response to anti-TNF treatment. This is reflected by efforts that were not able to identify serological biomarkers which could be used as standalone tools in clinics. Accordingly, conduct, analysis and interpretation of studies in IBD may be constrained to varying degrees by the prevalence of the disease at times. An individualized medicine with regard to identified proteins based on comparative studies is almost impossible.

In our IBD group including CD and UC patients, the percentage of 'positive responders' was higher than already reported ( 75 and $67 \%$, respectively). This might be explained by the transversal study setup were some patients were already in remission in both groups when infliximab therapy was started. Since the clinical data of the patients were blinded when the PIMS experiments were performed, we still included these patients in our study and assessed if anti-TNF therapy was able to maintain remission during the study time. We postulated that the maintenance of remission during the study period could be assessed as 'positive response' to infliximab.

Using an observation method that allows discrimination on the basis of morphological differences within a patient group with the same pathology would pave the way for further developments that would include the isolation and identification of biomarkers. PIMS is an exploratory technology able to highlight characteristic morphological protein assemblies within a tissue. The observed effect of infliximab on the responders' population could be explained by the fact that macromolecular interactions were preserved due to physiological conditions. There was no addition of any anti-phosphatase or antiprotease cocktails, nor were any denaturing or reducing agents used, which might have had an impact on serological biomarkers and could have influenced the results. Physiological osmolality and cellular ion composition were not altered. In fact, in responder groups, infliximab affects macromolecular assemblies. It changes thermodynamic relations in and between macromolecular assemblies as well as those with intrinsic water molecules. This would change molecular enthalpies and therefore result in a defrosting pattern. We performed continuous sampling from -37 to $37^{\circ} \mathrm{C}$ and changes were compared as a function of time and temperature. The temperature is a necessary component for two reasons: freezing amplifies the signal and its sensitivity, and therefore allows discrimination between the patients. There are intraindividual differences in cellular composition and specific protein concentration which lead to different freezing times. Furthermore, at $-37^{\circ} \mathrm{C}$ some molecular resonance will attenuate more than another (thanks to the quaternary structure of the proteins). The longer it takes to defrost, 
the higher the molecular interaction which would therefore affect the pattern of scattered light $[21,22]$. If infliximab has an impact on protein structure, their resonance will be changed in a frozen state. These changes are dynamic since temperature rises continuously.

PIMS gives precise morphological information on the patient's total PBMC protein and macromolecules in the presence of infliximab. This is due to molecular resonance within and between molecules, which can be deduced thanks to the Schrödinger equation, where only two components, space $(\mathrm{x})$ and time $(\mathrm{t})$, are considered. The probability of a molecule to move in space and meet another particle has been considered as one of the bases of quantum physics and underlines nuclear magnetic resonance technology. Another well-established law in quantum physics is the infrared absorption known as Raman spectra. The changes in molecular absorption spectra at 1-5 $\mu \mathrm{M}$ give precise information on molecule size and its relation to the surrounding environment [28-32]. PIMS combines molecular resonance and infrared spectra. The molecular resonance is mostly related to surrounding water molecules as their resonance is different on the surface of proteins, within the quaternary structure of the same protein or totally free from any contact with proteins [33-36]. When a protein changes its conformation (infrared spectroscopy), it changes also the resonance of related water molecules and therefore their absorption spectra.

PIMS discriminated three different groups. We observed differences at baseline among the patients. One reasonable explanation could be the ongoing anti-TNF therapy in most of the patients. This would have some impact on molecular resonance. We did not have any idea about the presence of anti-TNF antibodies or infliximab trough levels at the moment of blood sampling. In future studies, this should be completed by adapted immunochemical assays both in sera and on PBMC.

If infliximab interacts with the patient's PBMC protein assembly and modifies the molecular resonance in such way that it initiates a cascade of reactions extending to surrounding proteins and changes the mean molecular resonance for all existing macromolecules in a given time, it would reflect its pharmacological activity in vivo (it mimics the cellular signalization cascade).

Here, PIMS has shown to be a promising tool for the stratification of patients into responders and nonresponders. We have chosen a transversal, small-size clinical study in order to challenge the PIMS technology. It was important to see whether this technology was able to discriminate a specific pattern among the patients disregarding their gender, age, treatment and treatment duration. It was also important to challenge its robustness with respect to study size. We are currently running a longitudinal study where these points are addressed in patients during follow-up. Further investigations are needed to see whether PIMS could be a reliable predictor of the efficacy of anti-TNF treatment.

\section{Disclosure Statement}

M.F.N., R.A. and M.B. have served as advisors for MSD and Abbott. The authors declare that no financial or other conflict of interest exists in relation to the content of the article.

\section{References}

$>1$ Reenaers C, Louis E, Belaiche J: Current directions of biologic therapies in inflammatory bowel disease. Therap Adv Gastroenterol 2010;3:99-106.

2 Ghosh S, Panaccione R: Anti-adhesion molecule therapy for inflammatory bowel disease. Therap Adv Gastroenterol 2010;3:239-258.

$>3$ Rutgeers P, Sandborn WJ, Feagan BG, Reinisch W, Olson A, Johanns J, Travers S, Rachmilewitz D, Hanauer SB, Lichtenstein GR, de Villiers WJ, Present D, Sands BE, Colombel JF: Infliximab for induction and maintenance therapy for ulcerative colitis. N Engl J Med 2005;353:2462-2476.

-4 Hanauer SB, Hanauer SB, Sandborn WJ, Rutgeerts P, Fedorak RN, Lukas M, MacIntosh D, Panaccione R, Wolf D, Pollack P: Human anti-tumor necrosis factor monoclonal antibody (adalimumab) in Crohn's disease: the CLASSIC-I trial. Gastroenterology 2006;130: 323-333.
5 D’Haens G: Risks and benefits of biologic therapy for inflammatory bowel diseases. Gut 2007;56:725-732.

6 Sprakes MB, Ford AC, Warren L, Greer D, Hamlin J: Efficacy, tolerability, and predictors of response to infliximab therapy for Crohn's disease: a large single centre experience. J Crohns Colitis 2012;6:143-153.

$>7$ Moore RA, Derry S: Systematic review and meta-analysis of randomised trials and cohort studies of mycophenolate mofetil in lupus nephritis. Arthritis Res Ther 2006;8:R182.

-8 Franke A, McGovern DP, Barrett JC, Wang K, Radford-Smith GL, Ahmad T, Lees CW, Balschun T, Lee J, Roberts R, Anderson CA, Bis JC, Bumpstead S, Ellinghaus D, Festen EM, Georges M, Green T, Haritunians T, Jostins L, Latiano A, Mathew CG, Montgomery GW, Prescott NJ, Raychaudhuri S, Rotter JI, Schumm P, Sharma Y, Simms LA, Taylor KD, Whiteman D, Wijmenga C, Baldassano RN,
Barclay M, Bayless TM, Brand S, Büning C, Cohen A, Colombel JF, Cottone M, Stronati L, Denson T, De Vos M, D'Inca R, Dubinsky M, Edwards C, Florin T, Franchimont D, Gearry R, Glas J, Van Gossum A, Guthery SL, Halfvarson J, Verspaget HW, Hugot JP, Karban A, Laukens D, Lawrance I, Lemann M, Levine A, Libioulle C, Louis E, Mowat C, Newman W, Panés J, Phillips A, Proctor DD, Regueiro M, Russell R, Rutgeerts P, Sanderson J, Sans M, Seibold F, Steinhart AH, Stokkers PC, Torkvist L, Kullak-Ublick G, Wilson D, Walters T, Targan SR, Brant SR, Rioux JD, D’Amato M, Weersma RK, Kugathasan S, Griffiths AM, Mansfield JC, Vermeire S, Duerr RH, Silverberg MS, Satsangi J, Schreiber S, Cho JH, Annese V, Hakonarson H, Daly MJ, Parkes M: Genome-wide meta-analysis increases to 71 the number of confirmed Crohn's disease susceptibility loci. Nat Genet 2010;42:1118-1125.
Predicting Response to Anti-TNF

Therapy in IBD with PIMS 
-9 Jostins L, Ripke S, Weersma RK, Duerr RH, McGovern DP, Hui KY, Lee JC, Schumm LP, Sharma Y, Anderson CA, Essers J, Mitrovic M, Ning K, Cleynen I, Theatre E, Spain SL, Raychaudhuri S, Goyette P, Wei Z, Abraham C, Achkar JP, Ahmad T, Amininejad L, Ananthakrishnan AN, Andersen V, Andrews JM, Baidoo L, Balschun T, Bampton PA, Bitton A, Boucher G, Brand S, Büning C, Cohain A, Cichon S, D'Amato M, De Jong D, Devaney KL, Dubinsky M, Edwards C, Ellinghaus D, Ferguson LR, Franchimont D, Fransen K, Gearry R, Georges M, Gieger C, Glas J, Haritunians T, Hart A, Hawkey C, Hedl M, Hu X, Karlsen TH, Kupcinskas L, Kugathasan S, Latiano A, Laukens D, Lawrance IC, Lees CW, Louis E, Mahy G, Mansfield J, Morgan AR, Mowat C, Newman W, Palmieri O, Ponsioen CY, Potocnik U, Prescott NJ, Regueiro M, Rotter JI, Russell RK, Sanderson JD, Sans M, Satsangi J, Schreiber S, Simms LA, Sventoraityte J, Targan SR, Taylor KD, Tremelling M, Verspaget HW, De Vos M, Wijmenga C, Wilson DC, Winkelmann J, Xavier RJ, Zeissig S, Zhang B, Zhang CK, Zhao H; International IBD Genetics Consortium (IIBDGC), Silverberg MS, Annese V, Hakonarson H, Brant SR, Radford-Smith G, Mathew CG, Rioux JD, Schadt EE, Daly MJ, Franke A, Parkes M, Vermeire S, Barrett JC, Cho JH: Host-microbe interactions have shaped the genetic architecture of inflammatory bowel disease. Nature 2012;491:119-124.

10 Stockmayer WH, Stanley HE: Light-scattering measurement of interactions between unlike polymers. J Chem Phys 1950;18:153-154.

11 Timasheff SN, Robinson RA: The location of electrostatic charges in Kirkwood's model of organic ions. J Am Chem Soc 1957;79:782.

-12 Abbott NL, Blankschtien D, Hatton TA: Protein partitioning in two-phase aqueous polymer systems. 1. Novel physical pictures and a scaling-thermodynamic formulation. Macromolecules 1992;25:3917.

$\$ 13$ Moon YU, Curtis RA, Anderson CO, Blanch HW, Prausnitz JM: Protein-protein interactions in aqueous ammonium sulfate solutions. Lysozyme and bovine serum albumin (BSA). J Solution Chem 2000;29:699.

-14 Skouri M, Lorber B, Giege R, Munch JP, Candau JS: Effect of macromolecular impurities on lysozyme solubility and crystallizability: dynamic light scattering, phase diagram, and crystal growth studies. J Cryst Growth 1995; 152:209-220.
5 Narayanan J, Liu XY: Protein interactions in undersaturated and supersaturated solutions: a study using light and $\mathrm{x}$-ray scattering. Biophys J 2003;84:523-532.

16 Liu W, Bratko D, Prausnitz JM, Blanch HW: Effect of alcohols on aqueous lysozyme-lysozyme interactions from static light-scattering measurements. Biophys Chem 2004;107:289298.

17 van den Berg B, Chung EW, Robinson CV, Mateo PL, Dobson CM: The oxidative refolding of hen lysozyme and its catalysis by protein disulfide isomerase. EMBO J 1999;18: 4794-4803.

18 Cheung MS, Klimov D, Thirumalai D: Molecular crowding enhances native state stability and refolding rates of globular proteins. Proc Natl Acad Sci USA 2005;102:4753-4758.

19 Ellis RJ, Minton AP: Protein aggregation in crowded environments. Biol Chem 2006;387: 485-497.

20 Richter K, Nessling M, Lichter P: Macromolecular crowding and its potential impact on nuclear function. Biochem Biophys Acta 2008; 1783:2100-2107.

21 Fullerton GD, Cameron IL: Water compartments in cells. Methods Enzymol 2007;428: $1-28$.

22 Graziano G: Hydration entropy of polar, nonpolar charged species. Chem Phys Lett DOI: 10.1016/J.cplett.2009.07.01.

23 Arrondo JL, Muga A, Castresana J, Goñi FM: Quantitative studies of the structure of proteins in solution by Fourier-transform infrared spectroscopy. Prog Biophys Mol Biol 1993;59:23-56

24 Siebert F: Infrared spectroscopy applied to biochemical and biological problems. Methods Enzymol 1995;246:501-526.

25 Jackson M, Mantsch HH: The use and misuse of FTIR spectroscopy in the determination of protein structure. Crit Rev Biochem Mol Biol 1995;30:95-120.

26 Goormaghtigh E, Cabiaux V, Ruysschaert JM: Determination of soluble and membrane protein structure by Fourier transform infrared spectroscopy. III. Secondary structures. Subcell Biochem 1994;23:405-450.

27 Arrondo JL, Goñi FM: Structure and dynamics of membrane proteins as studied by infrared spectroscopy. Prog Biophys Mol Biol 1999;72:367-405.
28 Haris PI, Chapman D: Does Fourier-transform infrared spectroscopy provide useful information on protein structures? Trends Biochem Sci 1992;17:328-333.

29 Dioumaev AK: Infrared methods for monitoring the protonation state of carboxylic amino acids in the photocycle of bacteriorhodopsin. Biochemistry (Mosc) 2001;66:12691276.

30 Kauffmann E, Darnton NC, Austin RH, Batt C, Gerwert K: Lifetimes of intermediates in the beta-sheet to alpha-helix transition of beta-lactoglobulin by using a diffusional IR mixer. Proc Natl Acad Sci USA 2001;5:98:66466649.

31 Pozo Ramajo A, Petty SA, Starzyk A, Decatur SM, Volk M: The alpha-helix folds more rapidly at the $\mathrm{C}$-terminus than at the $\mathrm{N}$-terminus. J Am Chem Soc 2005;127:13784-13785.

-32 Lin S-Y, Li MJ, Cheng WT: FT-IR and Raman vibrational microspectroscopies used for spectral biodiagnosis of human tissues. Spectroscopy 2007;21:1-30.

33 Yang C, Brown JN, Kopple KD: Peptide water association in peptide crystals. Int J Peptide Res 1979;14:12-20.

34 Klotz IM: Protein hydration and behaviour: many aspects of protein behavior can be interpreted in terms of frozen water of hydration. Science 1958;128:815-822.

35 Frank HS, Evans MW: Free volume and entropy in condensed systems. J Chem Phys 1945;13:507-532.

36 Paker KJ: Nuclear spin relaxation studies of molecules absorbed on surfaces; in Einsley JW, Feeney J, Suteliffe LH (eds): Progress in Nuclear Magnetic Resonance Spectroscopy. New York, Pergamon Press, 1971.

- 37 Nichita C, Stelle M, Vavricka S, El-Wafa Ali A, Ballabeni P, de Saussure P, Straumann A, Rogler G, Michetti P: Clinical experience with adalimumab in a multicenter Swiss cohort of patients with Crohn's disease. Digestion 2010; 81:78-85.

38 Rutgeers P, Sandborn WJ, Feagan BG, Reinisch W, Olson A, Johanns J, Travers S, Rachmilewitz D, Hanauer SB, Lichtenstein GR, de Villiers WJ, Present D, Sands BE, Colombel JF: Infliximab for induction and maintenance therapy for ulcerative colitis. N Engl J Med 2005;353:2462-2476.

39 Vermeire S, Van Assche G, Rutgeerts P: Creactive protein as a marker for inflammatory bowel disease. Inflamm Bowel Dis 2004;10: 661-665. 